\title{
An Analysis of Grammatical Errors in Writing Recount Text at the Eighth Grade of SMP Negeri 20 Kota Jambi
}

\section{Selvia Lisa Asni, Susi Susanti}

STKIP Al-AzharDiniyyah, Jambi, Indonesia.

Email: selvialisaasni@gmail.com

How to cite this paper: Asni, S., \& Susanti, S. (2018). An Analysis of Grammatical Errors in Writing Recount Text at the Eighth Grade of SMP Negeri 20 Kota Jambi. International Journal of Language Teaching and Education, 2(2), 131-144. https://doi.org/10.22437/ijolte.v2i2.520 5

Received: May 16,2018

Accepted: June 22, 2018

Published: July 31,2018

Copyright (C 2018 by author and IJoLTe This work is licensed under the Creative Commons Attribution International License (CC BY 4.0).

(c) (7)

\begin{abstract}
This study aims to analyze and classify the types or mistakes of students using simple past tense in writing recount text. In addition, this study also aims to identify the cause of errors made by the students using simple past tense in writing recount text. This research used qualitative method with case study approach. Furthermore, the researchers chose the $8^{\text {th }}$ grade students and observed 26 students. The researchers used a written test and interviews to gain the data from student participants and an English teacher partcipant. Based on this research, it is found that students do all kinds of errors (omission, addition, selection and misordering). The type of error most often done by the students was omission error with 166 errors or $38.97 \%$. The second position was a selection error with 162 errors or $38.03 \%$. The third position was the addition error with 67 errors or $15.73 \%$. Then the last last error was misordering error with 31 errors or $7.28 \%$. In addition, the errors were caused by the complexity of the English system itself and not because of the influence of the Indonesian system (intralingual transfer). Moreover, students lacked of understanding of the grammar that became the cause of the error. In this study, most students did not understand verb forms (present and past form of the verbs) as well as the proper use of "be" in a sentence. This suggested that students had difficulty with the use of grammar in writing
\end{abstract}

\section{Subject Areas}

Writing

Keywords

error analysis, types of error, sources of error

\section{Introduction}

English is the primary language that dominates all aspects of international communication. This is supported by Kachru 1986 (in Fahrawaty, p. 3) likens English as Aladdin's lamp, which means that when someone has mastered then one can easily get in business, technology, and knowledge. In addition, English is also a foreign language in 
Indonesia. This is in accordance with the Decree of the Minister of Education and Culture No. 096 (1967) which states that English is as the first foreign language taught formally.

In learning the language, students must have language skills. Language skills has four components. They are listening, speaking, reading, and writing. Each of these skills relates one to another. In the process of learning English in school, writing skills are the most dominant skills taught. Writing is a language skill that is used to communicate indirectly. In writing, a person must be skilled at developing new ideas and in every paragraph well and skillfully exploiting and using the grammar and vocabulary. Therefore, aspects of grammar in writing can not be eliminated.

The principle of writing in English or Indonesian is not much different. However, the rules of grammar structures used in the English language are different to the rules of grammar structures in Indonesian. Examples of these differences are that the English language has tenses (time) to indicate the time while Indonesian has no specific grammatical forms to express time.

In August 2017, the reseracherser, conducted a short interview with a teacher of English at SMP Negeri 20 Kota Jambi. From this interview, the writer got an information that errors are often made by the students. This is supported by Nawaz, Umer, Tabasum, Zaman, Batool, \& Aslam (2015, p. 2) statement saying that grammar is one of the biggest problems found by the students. Grammar is a form of words from the language itself and their combinations in phrases, clauses and sentences. It can be said that the grammar gives rules about how to combine words into sentences. In the process, students are not separated from language errors. Grammatical errors is influenced by several factors, such as lack of understanding in learning English and the mother tongue influence. Error is part of learning English (Khansir, 2012). Mistake is error of performance. While error is error of competence. The cause of mistake is not related to language skills or knowledge of the language system. Mistake that occurs can be recognized and corrected by the speakers themselves. While errors are errors that occur systematically and not easily repaired properly by the students themselves because of a lack of language knowledge or competence. Therefore, the process to correct errors in order to improve language skills is needed.

There is an effective strategy to analyze grammatical errors. In this study, the researchers use a strategy taxonomy. Strategy taxonomy is the strategy proposed by Dulay, Burt and Krashen in 1982. This strategy is used to find errors made by the students. Dulay et al., 1982 (in Sompong, 2014, p. 116) taxonomy divides into four sections. They are error of omission, error of addition, errors of selection, and error of missordering. Based on the explanation above, grammar has a very important role in writing. In this study, the reserachers focused on analysing grammatical error of the recount text. Problems often found in the writing of the text recount are structures. In recount text grammar students should use the past tense when writing sentences. The use of the past tense is considered more difficult than the present tense.

From the description above, the researchers analyzed the error using the strategy taxonomy. They consist of error of omission, error of addition, error of selection and error of missordering. In this study, the writer will want to know the form of grammatical errors made by the students. Then, the writer will want to know the cause of the error in writing the text recount. The object to be studied is the eighth grade students of SMP Negeri 20 Kota Jambi. Based on the above statements, the writer is interested in doing a study entitled "An Analysis of Grammatical Errors in Writing Recount Text at the Eighth Grade of SMP Negeri 20 Kota Jambi". 


\section{Literature Review}

From Writing skills is one of the language skills learned by students in the school. Writing skills are useful to support the teaching and learning process. Through writing skills, students are required to be creative and active in thinking and activities as much as possible to pour their ideas into written language.

Writing can strengthen grammatical forms(Homstad \& Thorson, 1994, p. 29). That is because when someone is writing then he will process many words to create meaningful posts. According to Hartley 2008 (in Fitzmaurice \& O'Farrell, p. 7) that writing is an interactive process. It mean that in writing there are a lot of activities to do. When someone writes, there is an activity of thinking, designing posts, editing posts, and reviewing them again. Writing is a capability that is supported by creativity in thinking to produce an article of thoughts. Writing is something creative to express an idea, thoughts, and feelings in the form of a post. The meaning of being creative is to be able to connect among the ideas and language.

According to Nurgiantoro 1988 (in Wijayanti, 2015, p. 32), writing is a productive skill. Being productive is an activity that can produce something positive. Productive writing is a writing activity that can produce a work that is created from humans. Humans who process words and combine them in writing to produce a reading such as novels, articles, short stories, scientific papers and other types of reading. The ability to write is not a capability that is obtained automatically. The ability to write is not inborn, but it is obtained from a continuous learning. Writing is not an instant ability of a person. The ability to write is owned by someone because of a continuous learning which is finally resulted in an article. Writing is the result of good combination among the training process of writing, thinking, and word processing.

In addition, the activity of writing also has many purposes. Writes aims to tell a story, to provide guidance or direction, to clarify something, to persuade someone, to summarize. According to Syarif, Zulkarnaini, \& Sumarmo (2009, p. 6) the purpose of writing is to provide information, to persuade, to educate, and to entertain. There are many people who write in this world. That is because writing also has a lot of benefits for a person. Komaidi 2007 (in Rofi'ah, 2011, p. 24) mentions some benefits of writing activities:

1. Creating curiosity,

2. Encouraging to find references (such as books, magazines, newspapers, journals and the like) to improve the knowledge of what will be written,

3. Training to join minds and arguments in a systematic and logical thought,

4. Reducing the level of tension and stress,

5. Getting inner satisfaction and helping economically

6. Making the writer popular and well-known.

Recount text is written to inform about events in the past. Recount is a kind of genre that has social function to retell event for informing or entertaining(Azhar, 2015, p. 15). The purpose of this text is to retell the events with the aim of informing or entertaining the readers.

Derewianka 1990 (Kurnia, 2015, p. 26) explains that the recount text consists of three types. They are Personal Text Recount which consists of information or a story that is a personal experience of the author of the text. For example, the diary of a person, or a biography, etc. Then, Factual Recount Text that contains a report about real events that really had happened. For example, a police report, a science experiments report, record historical events report and cultural report. The last, Imaginative Recount which contains a story of imagination which recounts the results of the author's imagination. For example, a fiction in short stories, novels etc. 
Recount text has a linguistic feature. Boardman 2008 (in Saragih, Silalahi, \& Pardede, 2014, p. 57) the language features that are usually found on recount text, are as follows:

1. The use of nouns and pronouns to identify people, animals or things involved.

2. The use of the verbs to describe the events the past.

3. The use of past events related to the speaker or researcher`s time.

4. The use of conjunctions and connecting times of event sequence.

5. The use of adverbs and adverbial phrases to describe the place and time.

6. The use of adjectives to describe nouns.

The writer concludes that the linguistic features found in the recount text are as follows: Focus on individual participants, use of past tense, focus on sequence of events which explains the sequence of events in the recount text, and it uses material/action clauses which means all words, sentences, clauses describe an action of the story in the recount text.

In the process of language, language cannot be separated from grammar. That is because grammar has a very important meaning. Grammar explains the sentence structure. Grammar can identify smaller units of sentences (Hewings \& Hewings). Grammar gives a clear rule of how a sentence is formed and meaningful.According to Yule (2010, p. 83)grammar is the process of describing the structure of phrases and sentences, all the elements of grammar in a language, and the set of language order. It is a system that contains the rules of language. These rules are used to produce good and correct sentence. Grammar makes a person easily understand a word or writing. Grammar determines how to compose words.

In speaking errors will be found. They are mistakes and errors. The mistake is a deviation that is not intentionally spoken or written by a speaker, and can easily be repaired by the speaker him/herself. All people, native and non-native speakers, can make mistakes. By ccontrast, the error is a deviation from grammatically correct because someone does not understand the rules of grammar. Therefore, these speakers usually cannot immediately correct the error. Errors usually occur systematically and are often repeated. Speakers will know if the errors are notified by other speakers or teachers. This is supported by James 1998 (In Brown, 2007, p.258) that says that the difference between an error and a mistake is that an error can not be corrected itself while mistake can be corrected by someone. The error could improve the achievement of teachers in the teaching process. Because the teacher can evaluate the errors and correct them. So, the errors will not be repeated in the future.

Before entering into the strategy analysis, the writer will explain about the understanding of the error analysis. Cholipah (2014, p. 6) states that, "Error analysis provides a broader range of possible explanations than contrastive analysis for researchers/teachers to use to account for errors". So the error analysis can clearly describe the fault location. In addition, error analysis can be useful for someone (such as a teacher or a researcher) to find a solution to the error so that it will not be repeated.

One way to get an explanation of the error analysis is by using a surface strategy taxonomy. Dulay et al. (1982, p. 150) explains that "A surface strategy taxonomy highlights the ways surface structures which are altered: Learners may omit necessary items or add unnecesary ones, they may misform items or misorder them." It can be concluded that the surface strategy taxonomy can give an explanation of grammatical errors made by someone. Someone eliminates or adds elements that are are not important and not in accordance with the grammar.

Through the surface strategy taxonomy, it would be easy to know how far a student's ability to understand grammatical language. Additionally, the presence of errors in the description can be obtained from the surface strategy taxonomy then the teacher will 
know the solution to a mistake made by the student. The solution is by giving the additional training that is focused on mastering comprehension. Therefore, surface strategy taxonomy is needed by English teachers to know them

students. Based on the location of the fault, surface strategy taxonomy consists of four elements. They are errors omission, addition, selection, and misordering.

\subsection{Error of Omission}

Dulay et al. (1982, p. 154) says that "Omission errors are characterized by the absence of an item that must appear in a well-formed utterance". Error of omission is an error that does not present an item that should exist in a sentence.

For example: I a teacher (Incorrect sentence)

From the explanation and example above, there is a missing item. The word "I" here is noun. After the noun must be followed by "to be" in the simple present tense. To be from the word "I" is "am". So, the correct sentence is : I am a teacher.

\subsection{Error of Addition}

Error of addition is an error to add an item that should not exist in a sentence. Dulay et al. (1982, p. 156) explains that "Addition errord are the opposite of omissions. They are characterized by the presence of an item which must not appear in a well-formes utterance."

For example: They were didn't go to Bali (Incorrect sentence)

From the example above, the addition of items that are not necessarily is there. This sentence uses the negative word "were" did not followed by an infinitive verb. It should be in a simple past tense sentence. Before the word "did not" it should not be pheceded by tobe "were". So, the correct sentence is: They didn't go to Bali

\subsection{Error of Selection}

Dulay et al. (1981, p. 158) describes selection that is "Misformation/selection errors that are those characterized by the use of the wrong form of the morpheme or structure." This error usually occurs because the student is wrong in choosing the right words.

For example : You care about I(Incorrect sentence)

From the above example, the error lies in the word $I$. The word $I$ means the subject. But in the above sentence the object "I" should use the object "me". So, the correct sentence is : You care about me.

\section{4. $\quad$ Error of Misordering}

Dulay et al. (1982, p. 162) explains that "Misordering errors are characterized by the incorrect placement of a morpheme or group of morphemes in an utterance." Misordering is an error in the preparation of the writing.

For example: You don't know who is he(Incorrect sentence)

Should be:You don't know who he is.

From the statement, the writer concludes that the error analysis is a way to look at the error made by the students. This is because in the learning process students will make errors. These errors can affect the meaning of a sentence. Grammatical errors can also make a person difficult to understand a reading context. So, the students should be able to understand the rules of English grammar and how to apply it, especially in writing.

\subsection{The Sources of Error}

In addition to analyzing the grammatical error using a strategy taxonomy, it will also be discussed about the source of the errors. How did the error happen? By trying to identify 
the source of the errors, then the teacher will be able to take steps to solve the problem of grammatical errors in students. According to Brown (2007), there are four sources of errors; interlingual transfer, intralingual transfer, context of learning, and communication strategies.

\subsection{Interlingual Transfer}

Interlingual transfer is an error caused by the student's first language. It is caused by the change of the first language elements into a second language. Brown (2007), says that "The beginning stages of learning a second language are especially vulnerable to interlingual transfer from the native language, or interference". This is because the mother tongue is the only language used by the students before the second language.

For example: I studyand then I cooke yesterday.

To know the interlingual error, the writer finds it by translating the grammatical form of the student's first language. From the example above, it can be seen that students are still using grammatical the first language. The students do not change "sudy" to "studied" and "cook" to "cooked". It is because the students do not use grammatical second language. So the correct sentence is : I studied and then I cooked yesterday.

\subsection{Intralingual Transfer}

Interlingual transfer contributes a large error compared to interlingual errors in a second language (Brown, 2007). The intralingual error is the student's error in learning a second language caused by the complexity of the second language system.

For example: She buyed vegetables

From the example above, the students do intralingual transfers. Students know the rules in simple past tense. The students know that simple past tense use past form, by adding "ed". The students make errors. Not all verbs in simple past tense should be added by "ed". That is because in English there are two types of verbs. They are regular verbs and irregular verbs. For regular verbs, it is correct if added by "ed". For irregular verbs, it will be wrong if added by "ed". In the above example the word buy should be bought. So the correct sentence is: She boughtvegetables.

\subsection{Context of Learning}

The context of learning is the source of error from the situation in the classroom, teacher, and the material or textbook of the second language. Brown (227), mentions that context refers, for example, to the classroom with its teacher andits material in the case of school learning or the social situation inthe case of untutored second language learning. Students make error because of incorrect explanations from teachers, incorrect material delivery structures in textbooks, and less supportive class situations.

\subsection{Communication Strategies}

According to Brown 1980 (in Bayinah, 2013) communication strategy is a verbal or nonverbal mechanism for communicating the idea of using the right language. Any learning, must have a strategy. Similarly, in learning this second language. Students must have a strategy to improve their skills in learning a second language. But sometimes this strategy can be a source of errors. In other words, there are some sources that can cause errors in learning a second language. The source can come from the first language disturbance to the second language, the second language competence, and the student learning strategy. The sources of this error include interlingual and intralingual transfer processes, as well as the context of learning when the students try to send messages to the listeners or readers by Brown 1987 (in Suroso, 2015) 


\section{Method}

The researchers employed a qualitative method. In the qualitative method, the research process begins with an observation or symptoms. So the writer presents data collected with words instead of numbers. By using qualitative method, the researcher looks for all required data. Qualitative research has characteristics. Qualitative research seeks to provide an understanding of the problems associated with popolation (Mack, Woodsong, Macqueen, Guest, \& Namey, 2011, p. 1).

Based on the nature of the problem, this study can be categorized as a case study. According to (Castellan, 2010, p. 5) case study is a detailed study of an event. This statement explains that the case study is a study that examines a case or event in detail and depth. This study was conducted at SMP Negeri 20 Kota Jambi. The located school is at Jl. Abdul Muis, Talang Sari, Talang Bakung, Jambi City. Subjects in this studyis one class which consist of twenty-six students at the eighth grade of SMP Negeri 20 Kota Jambi. The participants in the study are twenty-six eight grade students from one class. Students are ranging from 13 to 14 years old. All participants is female.

This study used two types of instruments, test and interview. The first, the researchers entered the class and introduced themselves. The researchers let the participants know the writer's purpose to come to the class. The researchers distributed worksheets to each student in the class. The researchers explained what the students should do in the written test. After that, the researchers gave time to students to do the written test about the recount text. After the students finish working, the researchers took and collected all the written test.

The second step, the researchers conducted the interview. Interview is a supporting instrument. Interviewees were interviewed on the same day after they finish their class. Interviews were done to only 3 students and 1 teacher. The researchers recorded the interview process. The result of the recording was printed in tapescripts.

The researchers used qualitative research in which the method is conveyed in descriptive analysis way to describe and to interpret the result of qualitative data. To get qualitative results, the data will be calculated by the formula of Allan 2004 (in Noviyanti, 2013, p. 30), as follows:

$$
\mathrm{P}=\frac{F}{\mathrm{~N}} X 100 \%
$$

$\mathrm{P}=$ Percentage

$\mathrm{F}=$ Frequency of error occurred

$\mathrm{N}=$ Number of cases (total frequent / total individual)

The researchers analyzed the data from written test and interview. First, the researchers corrected the errors of each student. The researchers classified the errors based on their location. After the errors were classified, the researchers calculated each total error (F / Frequency of the error occurred). How many errors of omission, errors of addition, errors of selection and errors of missordering. Then, the researchers calculated all errors occuring ( $\mathrm{N} /$ Number of cases / total frequent). So after that, the researchers looked for a percentage error using the formula of Allan. The researchers find the percentage of each error.

In addition, this written test was used to answer the cause of errors or sources of problems in writing. The researchers classified the source of the errors based on Brown's theory. Then, the researchers calculated the percentage of the source of the error with the formula from Allan. The second step was to analyze the results of the interviews. The collected interview data were also analyzed to support the data. 
across time periods and genres.

\section{Finding and Discussion}

The researchers did interviews on 25 August 2017 to 3 students and an English teacher. The researchers concluded that most of the students did not really understand about past tense materials in recount text. It was due to their confusion to distinguish between verb 1,2 , and 3 . In addition, the students also found it difficult to distinguish between the regular verbs and irregular verbs. Therefore, the students needed an assistance of dictionary to be able to distinguish them. The major difficulty for the students was to distinguish verb 1, 2, and 3 in the irregular verbs. They had a textbook but in fact they did not directly understand the materials by only reading the textbook. They needed a help of teacher to understand it more. Due to those problems the students then happpened a difficulty in dealing with writing recount text. The writer also found information that the students sometimes got wrong in memorizing the formula of past tense. One of the students who was interviewed said that the simple past used verb 3.

In addition, the results of interview with the English teacher showed that the teacher had taught the materials using "example sentences" method. The method was to give examples to the students and later to discuss them with the students in order the students to be able to understand the pattern of the sentences. The teacher also stated that the textbook was not really able to explain the materials in details. The students still needed an explanation from the teacher. Even the teacher also had to have other guidebooks like a specific grammar book. Similarly, the teacher encountered many difficulties from the students in writing recount text. The difficulties were similar to the one said by the students in previous interviews session. In addition, the teacher also said that the students often mixed Indonesian language into English. The students also often translated English through word by word. They adopted the similar pattern from Indonesian language. Of course it was wrong. One of the errors was that they sometimes forgot when to use tobe "was/were". They were also wrong to pick up a suitable word of verb 1,2 , and 3. To anticipate this, in the begining of the class the teacher shouldremind the students of previous materials. Then, the teacher also should always make a conclusion related to the lesson taught at the end of the class. This was done because the teacher knew that the students could easily remember but could easliy forget the lesson.

The researchers found many errors made by the students in writing the recount text. Any errors found were marked and corrected. After that the researchers classified each type of error and each source of error made by the students. Then the researchers calculated the number of each error by using the percentage.

In this section, the researchers identified the student's error in writing the recount text. Below was the result of problem identification: 
Table 4.1. The Recapitulation of the Student's Error

\begin{tabular}{|c|c|c|c|c|c|}
\hline \multirow[b]{2}{*}{ No. } & \multirow[b]{2}{*}{$\begin{array}{l}\text { Students } \\
\text { Number }\end{array}$} & \multicolumn{4}{|c|}{ Types of Error } \\
\hline & & $\begin{array}{l}\text { Error of } \\
\text { Omission }\end{array}$ & $\begin{array}{l}\text { Error of } \\
\text { Addition }\end{array}$ & $\begin{array}{l}\text { Error of } \\
\text { Selection }\end{array}$ & $\begin{array}{l}\text { Error of } \\
\text { Misordering }\end{array}$ \\
\hline 1 & Student 1 & 2 & 5 & 13 & - \\
\hline 2 & Student 2 & 8 & 1 & 1 & - \\
\hline 3 & Student 3 & 11 & 5 & 6 & - \\
\hline 4 & Student 4 & 3 & 3 & 8 & 2 \\
\hline 5 & Student 5 & 9 & 3 & 2 & - \\
\hline 6 & Student 6 & 4 & 2 & 7 & 2 \\
\hline 7 & Student 7 & 3 & 3 & - & - \\
\hline 8 & Student 8 & 4 & 2 & 5 & 3 \\
\hline 9 & Student 9 & 4 & - & 2 & - \\
\hline 10 & Student 10 & 3 & 1 & - & - \\
\hline 11 & Student 11 & 7 & 3 & 9 & 7 \\
\hline 12 & Student 12 & 6 & 4 & 1 & - \\
\hline 13 & Student 13 & 5 & 3 & - & - \\
\hline 14 & Student 14 & 3 & 4 & 4 & 6 \\
\hline 15 & Student 15 & 10 & 3 & 5 & 1 \\
\hline 16 & Student 16 & 19 & 4 & 15 & 3 \\
\hline 17 & Student 17 & 7 & 2 & 5 & - \\
\hline 18 & Student 18 & 10 & 3 & 13 & - \\
\hline 19 & Student 19 & 6 & 1 & - & - \\
\hline 20 & Student 20 & 1 & 2 & 6 & - \\
\hline 21 & Student 21 & 2 & 2 & 1 & - \\
\hline 22 & Student 22 & 2 & 3 & 2 & - \\
\hline 23 & Student 23 & 4 & 1 & 7 & - \\
\hline 24 & Student 24 & 4 & 1 & 3 & - \\
\hline 25 & Student 25 & 2 & 1 & 7 & 5 \\
\hline 26 & Student 26 & 27 & 5 & 40 & 2 \\
\hline \multicolumn{2}{|c|}{ Total of Each Error } & 166 & 67 & 162 & 31 \\
\hline \multicolumn{2}{|c|}{ Total of All Errors } & \multicolumn{4}{|c|}{426} \\
\hline
\end{tabular}

From Table 4.1 the percentage of each type of error was:

1. The Error of Omission $=\frac{166}{426} \times 100 \%=38.97 \%$

2. The Error of Addition $\quad{ }^{426}=\frac{67}{436} \times 100 \%=15.73 \%$

3. The Error of Selection $=\frac{436}{4266} \times 100 \%=38.03 \%$

4. The Error of Misordering $=\frac{4326}{426} \times 100 \%=7.28 \%$

Table 4.2. The Recapitulation of Error Types, Frequency and its Percentage

\begin{tabular}{clll}
\hline & & & Percent- \\
No & Types of Error & Frequency & age \\
\hline 1. & The Error of Omission & 166 & $38.97 \%$ \\
2. & The Error of Addition & 67 & $15.73 \%$ \\
3. & The Error of Selection & 162 & $38.03 \%$ \\
4. & The Error of Misordering & 31 & $7.28 \%$ \\
\hline \multicolumn{2}{c}{ Total } & $\mathbf{4 2 6}$ & $\mathbf{1 0 0 \%}$ \\
\hline
\end{tabular}


Table 4.3 The Recapitulation of Source of Student's Errors

\begin{tabular}{|c|c|c|c|}
\hline \multirow{2}{*}{ No. } & \multirow{2}{*}{$\begin{array}{l}\text { Students } \\
\text { Number }\end{array}$} & \multicolumn{2}{|c|}{ Source of Error } \\
\hline & & Interlingual Transfer & Intralingua Transfer \\
\hline 1 & Student 1 & 2 & 18 \\
\hline 2 & Student 2 & 8 & 2 \\
\hline 3 & Student 3 & 11 & 11 \\
\hline 4 & Student 4 & 5 & 11 \\
\hline 5 & Student 5 & 9 & 5 \\
\hline 6 & Student 6 & 6 & 9 \\
\hline 7 & Student 7 & 3 & 3 \\
\hline 8 & Student 8 & 7 & 7 \\
\hline 9 & Student 9 & 4 & 2 \\
\hline 10 & Student 10 & 3 & 1 \\
\hline 11 & Student 11 & 14 & 12 \\
\hline 12 & Student 12 & 6 & 5 \\
\hline 13 & Student 13 & 5 & 3 \\
\hline 14 & Student 14 & 9 & 8 \\
\hline 15 & Student 15 & 11 & 8 \\
\hline 16 & Student 16 & 22 & 19 \\
\hline 17 & Student 17 & 7 & 7 \\
\hline 18 & Student 18 & 10 & 16 \\
\hline 19 & Student 19 & 6 & 1 \\
\hline 20 & Student 20 & 1 & 8 \\
\hline 21 & Student 21 & 2 & 3 \\
\hline 22 & Student 22 & 2 & 5 \\
\hline 23 & Student 23 & 4 & 8 \\
\hline 24 & Student 24 & 4 & 4 \\
\hline 25 & Student 25 & 7 & 8 \\
\hline 26 & Student 26 & 29 & 45 \\
\hline \multicolumn{2}{|c|}{ Total of Each Error } & 197 & 229 \\
\hline \multicolumn{2}{|c|}{ Total All Errors } & \multicolumn{2}{|c|}{426} \\
\hline
\end{tabular}

Based on Table 4.3 it showed that the percentage of error sources was:

1. Interlingua transfer $=\frac{197}{426} \times 100 \%=46.24 \%$

2. Intralingua transfer $=\frac{229}{426} \times 100 \%=53.76 \%$

Table 4.4. The Recapitulation of Source of Error, Frequency, and its Percentage

\begin{tabular}{clll}
\hline No. & Source of Error & Frequency & Percentage \\
\hline 1. & Interlingua Transfer & 197 & $46.24 \%$
\end{tabular}




\begin{tabular}{llll}
2. & Intralingua Transfer & 229 & $53.76 \%$ \\
\hline Total & & $\mathbf{4 2 6}$ & $\mathbf{1 0 0 \%}$ \\
\hline
\end{tabular}

The Analyze of the errors was started with describing errors, next explaining errors, then evaluating errors. This procedure would be described clearly as follows:

\section{The Description of Error}

After identifying the data, the author analyzed the errors and classified them based on the Surface Taxonomy Categories to know the error of omission, error of addition, error of selection, and error of misordering.

The Error of Omission

There were 166 or $38.97 \%$ total errors of omission. The error occurred because the students omitted an element that should exist in a sentence. The omission of an element might affect the meaning of the sentence itself.

Example: I stayed in grandmother house for three days.

The correct sentence: I stayed in grandmother's house for three days.

From this example it was clear that students eliminated the morpheme -s as possessive markers. The cause of the students making this error is because in the grammatical structure of the Indonesian language there is no specific morpheme to declare possessive.

The Error of Addition

There were 67 or $15.73 \%$ total errors of addition.

Example: Day yesterday, I and my family went to Tebo city to visit my grandmother

The correct sentence: Yesterday, I and my family went to Tebo city to visit grandmother

This error occurred because the student added an item that should not exist in a sentence. The students had learned the grammatical rules of English, but they often misunderstood them. So, they then made that error.

The Error of Selection

There were 162 or $38.03 \%$ total errors of selection. This error occurred because the student was wrong in choosing the right words.

Example: When we returned home we were tired but we were happy because we can see some animals.

The correct sentence: When we returned home we were tired but we were happy because we could see some animals.

In the example above, the student made an error in choosing the correct auxiliary verb. When we tell about events in the past, the auxiliary verb "can" should be "could"

The Error of Misordering

There were 31 or $7.28 \%$ total errors of misordering. This error occurred because the students made errors in morpheme arrangements in sentences.

Example: We saw birds very beautiful

The correct sentence: We saw very beautiful birds

In the example above, the students were confused in the preparation of morphemes in the sentence. So, if there is an error in composing a sentence, it will affect the understanding of people who read or who listen to it.

\section{The Explanation of Error}

The writer classified errors based on the source of the error. In this case, the writer analyzed the error whether it came from the Indonesian language (interlingua) or came from English (intralingua). So that the writer would not use the sources of error based on context learning and communication strategies.

Interlingua Transfer

Example: Three dayago, I and my father went to Paris 
The correct sentence: Three days ago, I and my father went to Paris

In the example above, the students removed the item that should be there. The student had not understood if after a plural countable noun then the following word must be placed with phoneme -s which serves as a plural marker. This error occurred because the student was still influenced by the Indonesian language. There are striking differences between Indonesian and English such as from the time statement, mentioning plural and plural nouns. Although teachers have basically taught the grammatical English to the students, but in fact they still do not understand it. So, the source of the error came from the interlingua transfer.

\section{Intralingua Transfer}

Example: I and my friend going to my teacher's house

The correct sentence: I and my friend went to my teacher's house

In this sentence the student did not know that the verb in the past tense had to be changed into a past form. Where the second verb form of "going" is "went" The source of this error is the intralingua transfer.

The Evaluation of Error

The Interpretation of the Data

\section{Percentage of Students' Errors}

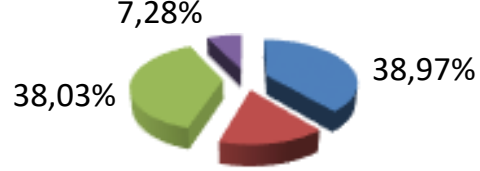

$15,73 \%$
The Error of Omission

The Error of Addition

Figure 4.5. Percentage of Students' Errors

Based on the calculation above, it could be concluded that the total error of omission was 166 errors or $38.97 \%$, error of addition was 67 errors or $15.73 \%$, error of selection was 162 errors or $38.03 \%$, while error of misordering was 31 errors or $7.28 \%$. From the calculation of the data, error of omission was the most frequent errors done by the students of SMP Negeri 20 Kota Jambi with the percentage of $38.97 \%$. It was followed by the error of selection in the second position with the percentage of $38.03 \%$. Error of addition was in the third position with $15.73 \%$. Furthermore, the error of misordering was in the last position with $7.28 \%$.

\section{Percentage of Students' Source of Errors}
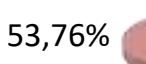

\author{
- Interlingual Transfer \\ - Intralingual Transfer
}


Figure 4.6. Percentage of Students' Source of Errors

The calculation of the data, the major source of errors made by students was intralingual with 229 errors or $53.76 \%$. Meanwhile there were 197 interlingua errors or $46.24 \%$. However, if seen specifically, there were 11 students (student 2, 5, 9, 10, 11, 12, 13, 14, $15,16,1)$ who made interlingual errors. In addition, there were 10 students (student 1 , $4,6,18,20,21,22,23,25,26)$ who made intralingual errors and there were only 5 students (student $3,7,8,17,24$ ) who made both interlingual and intralingual errors with the same frequency. This is supported by Brown in chapter 2 which said that interlingual transfer contributes a large error compared to interlingual errors in a second language.

\section{Conclusion}

Based on this research, the type of error most often done by the students on simple past tense in writing recount text was omission error with 166 errors or $38.97 \%$. The second position was a selection error with 162 errors or 38.03 . The third position was the addition error with 67 errors or $15.73 \%$. Then the last position was disordering error with 31 errors or $7.28 \%$. There was a very small difference between omission error and error selection with only 4 errors or $0.94 \%$.

The data showed that intralingua transfer was the main source of error. After doing the analysis, the author found that the errors of the students were caused by the complexity of the English system itself and not because of the influence of the Indonesian system. The fact that the students lacked understanding of the grammar in English became the cause of the error. In this study, most students did not understand verb1, 2, 3, as well as the proper use of "tobe" in a sentence. This suggested that students had difficulty with the use of grammar in writing.

\section{References}

[1] Azhar, S. (2015). Analysis Of Generic Structure Of Recount Texts (The Study Of Fourth Semester Students Of Stain Salatiga In The Academic Year Of 2012/2013). Salatiga: STATE Institute For Islamic Studies Salatiga.

[2] Bayinah, S. (2013). The Grammatical Error Analysis On Using The Simple Past Tense In Writing Recount Text (A Case Study At The First Grade On Ma Al Khairiyah), Jakarta: Syarif Hidayatullah State Islamic University

[3] Brown, H. D. (2007). Principles of Language Learning And Teaching (Fifth edition). New York Longman.

[4] Castellan, C. M. (2010). Quantitative and Qualitative Research: A View for Clarity. Macrotink Institute , 1-14.

[5] Cholipah. (2014). AN ANALYSIS OF STUDENTS' ERROR IN WRITING RECOUNT TEXT (A Case Study in the Second Grade Students of SMP Trimulia Jakarta Selatan). Jakarta: Syarif Hidayatullah STATE Islamic University.

[6] Dulay, H., Burt, M., and Krashen, S., (1982). Language Two. New York: Oxford University Press

[7] Fahrawaty. Bahasa Inggris Sebagai Bahasa Internasional Dan Pengaruhnya Terhadap Kurikulum Pembelajaran Bahasa Inggris Di Indonesia . Sulawesi Selatan: Widyaiswara LPMP

[8] Fitzmaurice, M., \& O'Farrell, C. Developing Your Academic Writing Skills: A Handbook. Dubli: University Of Dublin.

[9] Hewings, A., \& Hewings, M. Grammar And Context. Lonon \& New York: Routledge 
[10] Homstad, T., \& Thorson, H. (1994). Writing Theory and Practice in the Second Language Classroom: A Selected Annotated Bibliography. German: Universitas Of Minnesota

[11] Khansir, A. A. (2012). Error Analysis and Second Language Acquisition. Iran: Bushehr University of Medical Sciences and Health Services.

[12] Kurnia, F. F. (2015). Presented as partial fulfillment of the requirements for the attainment of Sarjana Pendidikan Degree on the English Language Education. Yogyakarta : Universitas Negeri Yogyakarta.

[13] Mack, N., Woodsong, C., Macqueen, K. M., Guest, G., \& Namey, E. (2011). Qualitative Research Methods: A Data Collector's Field Guide. USA: Family Health International.

[14] Nawaz, S., Umer, A., Tabasum, M., Zaman, M., Batool, A., \& Aslam, S. (2015). DIFFICULTIES FACING BY STUDENTS OF L1 IN ADOPTING L2. European Journal of English Language, Linguistics and Literature , 1-6

[15] Rofi'ah, E. (2011). Peningkatan Keterampilan Menulis Petunjuk Melakukan Sesuatu Dengan Metode Investigasi Kelompok Dan Media Video Pembelajaran Pada Siswa Kelas Viiie Smp Negeri 10 Tegal Tahun Ajaran 2010/2011. Semarang: Universitas Negeri Semarang.

[16] Saragih, N., Silalahi, R., \& Pardede, H. (2014). The Effectiveness of Using Recount Text to Improve Writing Skill For Grade III Students of Kalam Kudus Elementary School 2 Pematangsiantar.IOSR Journal Of Humanities And Social Science , 56-64

[17] Syarif, E., Zulkarnaini, \& Sumarmo. (2009). Pembelajaran Menulis. Jakarta: Departemen Pendidikan Nasional.

[18] Suroso, I., (2015). Grammatical Errors Dalam Presentasi Lisan Bahasa Inggris. Orbith, 132-138

[19] Wijayanti, N. S. (2015). Modul Pelatihan Simple Conversation. Yogyakarta: Universitas Negeri Yogyakarta.

[20] Yule, G. (2010). The Study Of Language Fourth Edition. New York: Cambridge University Press. 